\title{
Effects of Scutellariae Radix Extract on Lipid Metabolism, Oxidation and Production of Pro-Inflammatory Cytokines in Rats Fed Highly Oxidized Fat
}

\author{
Sung-Man Kim, Yun-Yeop Cha' \\ Department of Medical Management, College of Medicine, Catholic Kwandong University, 'Department of Rehabilitation Medicine of \\ Korean Medicine, College of Korean Medicine, Sangji University
}

Received: November 17, 2016 Revised: December 9, 2016 Accepted: December 12, 2016

Correspondence to: Yun-Yeop Cha Department of Rehabilitation Medicine of Korean Medicine, College of Korean Medicine, Sangii University, 80

Sangjidae-gil, Wonju 26339, Korea

Tel: +82-33-741-9260

Fax: +82-33-732-2124

E-mail: oringa@hanmail.net

Copyright $(\odot 2016$ by The Society of Korean

Medicine for Obesity Research
Objectives: This study investigated the effects of Scutellariae Radix extract (SRE) on lipids metabolism, oxidation and the production of pro-inflammatory cytokines in rats fed highly oxidized fat.

Methods: To induce obesity, male Sprague-Dawley rats were fed a highly oxidized fat diet for 10 weeks. SRE at $100 \mathrm{mg} / \mathrm{kg}$ were administered orally to obesity-induced rats for 6 weeks, and their lipid metabolism, oxidation and production of pro-inflammatory cytokines were examined.

Results: The concentrations of free fatty acid, triglyceride, total cholesterol, and low density lipoprotein-cholesterol in plasma decreased in SRE-treated groups, although the difference was not significant between control and SRE-treated groups, while that of high density lipoproteincholesterol significantly increased in SRE group. The concentrations of total cholesterol and triglyceride in the liver were tended to decrease in SRE-treated group. The concentrations of thiobarbituric acid in plasma and liver were lower in SRE group than in control group. The levels of glutamic oxaloacetic transaminase and glutamic pyruvic transaminase in plasma were decreased in SRE group. Activities of glutathione peroxidase, superoxide dismutase, and catalase in liver were tended to increase in the SRE group. The plasma concentrations of interleukin (IL)-1 $\beta$, tumor necrosis factor (TNF)- $\alpha$ and IL-6 were lower in SRE group than in control group, while that of IL-10 was higher. The liver concentrations of IL-1 $1 \beta$, TNF- $\alpha$, and IL- 6 were tended to decrease while that of IL-10 tended to increase in SRE group.

Conclusions: Finally SRE could be used in the production of nutraceuticals for lowering lipids and exerting anti-oxidation and anti-inflammatory effects in obesity rats fed highly oxidized rat.

Key Words: Scutellaria baicalensis, Pro-inflammatory cytokines, Oxidized fat, Anti-oxidation

\section{Introduction}

Highly oxidized fat in foodstuffs causes abnormal lipid metabolism and produces a high concentration of lipid peroxide ${ }^{1-3)}$, which in turn can cause biofunctional abnormalities such as degenerative problems, cancer, senescence, and membranous change and injury ${ }^{4-6)}$.

A high concentration of lipid peroxide also increases inflammation-mediating substances, abnormal cytokine production, and the activation of the inflammatory sig- naling mechanism, and these can exert negative effects on the immune system ${ }^{7-9)}$.

The recent increases in the consumption of high-fat and high-calorie foods are increasing the problem of abnormal lipid metabolism, which has prompted many studies investigating the use of natural products in the development of nutraceuticals ${ }^{10-13}$. Such nutraceuticals could be useful in lowering lipids and exerting antioxidant and anti-inflammatory effects.

Scutellariae Radix is the root of the perennial herb 
Scutellaria baicalensis Georgi. Its major components are flavonoid compounds, of which around 30 elements have been identified ${ }^{14)}$. The main biological functions of Scutellariae Radix, which are mainly attributable to flavonoids, include antihistamine effects ${ }^{15)}$, antiliver toxin ${ }^{16)}$, antibiosis $^{17)}$, anticancer ${ }^{18)}$, antibacterial activation ${ }^{19)}$, and anti-inflammatory effects ${ }^{20)}$. For example, baicalein (5, 6, 7-trihydroxyflavone) from Scutellariae Radix showed the same strong anti-inflammatory effect as sulfasalazine against dextran sodium sulfate exposure in animals ${ }^{21)}$. With the aim of developing nutraceuticals for lowering lipids and with antioxidant and anti-inflammatory effects, we administered Scutellariae Radix extract (SRE) to rats being fed highly oxidized fat. The lipid composition, anti-oxidation, and production of pro-inflammatory cytokines were examined.

\section{Materials and Methods}

\section{Animals and treatment}

Sixty male Sprague-Dawley rats weighing 173.59土 $6.21 \mathrm{~g}$ (mean \pm standard deviation [SD]) were fed a highly oxidized fat diet (Table 1) for 10 weeks. Forty rats that weighed at least $400 \mathrm{~g}$ were randomly assigned to four groups containing 10 rats each: a control group in which physiological saline solution $(100 \mathrm{mg} / \mathrm{kg})$ was administered, and three treatment groups in which SRE was administered at 100, 200, and $300 \mathrm{mg} / \mathrm{kg}$ by Zonde.

\section{Feeding}

A baseline diet was supplied equally to all groups (Table 1) for 6 weeks for experiment, with a maximum intragroup difference in the amount consumed of $5 \%$. The rats were allowed free access to water.

\section{Preparation of SRE}

Scutellariae Radix (500 g, dried weight, purchase from Korean medicinal store) was divided and extracted three times for 5 hours each in a cooling water reflux cistern using decompression concentrated and then extracted using methanol yield (120 g, 24\%). SRE was administered orally via a Jones tube at 5 p.m. daily for 6 weeks. The control group was given normal saline in the same form.

\section{Lipid peroxide assay}

Lipid peroxide was prepared by aeration and stirred with soybean oil heated to $60^{\circ} \mathrm{C}$ for 72 hours. The peroxide level was more than $200 \mathrm{meq} / \mathrm{kg}^{22)}$.

\section{Sampling}

Blood was collected after 14 hours of fasting using the heart puncture method on the last day of the experiment. Samples of approximately $7 \mathrm{ml}$ were collected and divided for individual analysis. Liver samples collected after blood sampling were processed according to specific biochemical analyses and stored at $-80^{\circ} \mathrm{C}$.

Table 1. Composition of Experimental Diets

\begin{tabular}{lcc}
\hline \multirow{2}{*}{ Ingredients (\%) } & \multicolumn{2}{c}{ Diets } \\
\cline { 2 - 3 } & Basal diet & Oxidized lipid diet \\
\hline Sugar & 50.00 & 44.74 \\
Corn starch & 12.00 & 10.74 \\
Casein & 20.00 & 17.89 \\
Corn oil & 8.00 & 7.16 \\
Cellulose & 5.00 & 4.47 \\
AlN-76 Mineral mix. & 3.50 & 3.50 \\
AIN-76 Vitamin mix. & 1.00 & 1.00 \\
DL-methionine & 0.30 & 0.30 \\
Choline chloride & 0.20 & 0.20 \\
Oxidized soybean oil & & 10.00 \\
Total & 100.00 & 100.00 \\
\hline
\end{tabular}

AlN-76 Mineral mix (g/kg): $\mathrm{CaHPO}_{4}(500), \mathrm{NaCl}(74), \mathrm{K}$ citrate monohydrate: $220, \mathrm{~K}_{2} \mathrm{SO}_{4}: 52, \mathrm{MgO}: 24, \mathrm{Mn}$ carbohydrate: 3.5, $\mathrm{Fe}$ citrate: $6.0, \mathrm{Zn}$ cabonate: $1.6, \mathrm{Cu}$ Carbonate: $0.3, \mathrm{KIO}_{3}: 0.01$, $\mathrm{Na}_{2} \mathrm{SeO}_{3} .5 \mathrm{H}_{2} \mathrm{O}: 0.01, \mathrm{CrK}\left(\mathrm{SO}_{4}\right)_{2} .12 \mathrm{H}_{2} \mathrm{O}: 0.55$, Sucrose: 118 . AlN-76 Vitamin mix $(\mathrm{g} / \mathrm{kg})$ : thiamin. $\mathrm{HCl}$ : 0.6, riboflavin: 0.6 , pyridoxine. $\mathrm{HCl}$ : 0.7 , nicotinic acid: 3 , D-calcium pantothenate: 1.6 , folic acid: 0.2 , D-biotin: 0.02 , cyanocobalamin: 0.001 , retinyl palmitate: $0.8(500,000$ $\mathrm{IU} / \mathrm{g})$, DL- $\alpha$-tocopheryl acetate: 20 (250 IU/g), cholecalferol: 0.00025, menaquinone: 0.005 . 


\section{Serological analysis}

Total plasma concentrations of cholesterol, total hepatic cholesterol, high density lipoprotein (HDL)-cholesterol, and triglyceride were measured using commercial kits (Wako, Japan). The plasma thiobarbituric acid (TBARS) concentration was quantified using the method of Buege and Aust ${ }^{23)}$. The hepatic TBARS concentration was measured by the method of Ohkawa et al. ${ }^{24)}$, and glutamic oxaloacetic transaminase (GOT) and glutamic pyruvic transaminase (GPT) activities in plasma were measured using an automatic blood-analyzing device (Boehringer Mannheim, Mannheim, Germany). The activities of glutathione peroxidase (GSH-Px), liver superoxide dismutase (SOD), and liver catalase (CAT) were measured using the methods of Levander et al. ${ }^{25)}$, Flohe et al. ${ }^{26)}$, and Johnson and Hakan Borg ${ }^{27)}$, respectively. The concentration of plasma free fatty acid was measured by the enzyme technique using the V-NEFA kit (Mitsui, Tokyo, Japan). The concentrations of cytokines (interleukin [IL]-1 $\beta$, tumor necrosis factor $[\mathrm{TNF}]-\alpha$, IL-6, and IL-10) were determined by enzyme-linked immunosorbent assays using commercial kits (Biosource International, Camarillo, CA, USA). The minimum detectable concentration of TNF- $\alpha$ was $0.7 \mathrm{pg} / \mathrm{ml}$, and those of the other cytokines were $3 \sim 8 \mathrm{pg} / \mathrm{ml}$. Hepatic amounts of cytokines were calculated per $1 \mathrm{~g}$ of wet tissue in $5 \mathrm{ml}$ of phosphate buffer saline. The concentrations of cytokines in plasma were expressed in pictograms per milliliter (pg/mg), and hepatic cytokine amounts were measured

Table 2. Effects of SRE on Plasma FFA and Triglyceride Concentration in Rat Fed Oxidized Fat

\begin{tabular}{lll}
\hline \multicolumn{1}{c}{ Treatment } & \multicolumn{1}{c}{ FFA (uEql) } & Triglyceride $(\mathrm{mg} / \mathrm{dll})$ \\
\hline Control & $872.74 \pm 43.25^{\mathrm{c}}$ & $298.31 \pm 37.92^{\mathrm{b}}$ \\
SRE $(100 \mathrm{mg} / \mathrm{kg})$ & $811.72 \pm 45.41^{\mathrm{bc}}$ & $257.11 \pm 41.65^{\mathrm{ab}}$ \\
SRE $(200 \mathrm{mg} / \mathrm{kg})$ & $783.44 \pm 37.95^{\mathrm{b}}$ & $232.48 \pm 35.51^{\mathrm{ab}}$ \\
SRE $(300 \mathrm{mg} / \mathrm{kg})$ & $652.38 \pm 39.72^{\mathrm{a}}$ & $203.52 \pm 31.11^{\mathrm{a}}$ \\
\hline
\end{tabular}

Values are presented as mean \pm standard deviation.

SRE: Scutellariae Radix extract, FFA: free fatty acid.

${ }_{a, b, c}$ Means in the same column with different superscripts are significantly different $(P<0.05)$. in picograms per milligram $(\mathrm{pg} / \mathrm{mg})$ of tissue.

\section{Statistical analysis}

Statistical analyses (mean \pm SD) were performed using one-way ANOVA with the PASW Statistics ver. 18.0 ${ }^{\circledR}$ for Windows (IBM Co., Armonk, NY, USA), and the cutoff for significance was $\mathrm{P}<0.05$ by Duncan's multiple range test.

\section{Results and Discussion}

Highly oxidized fat causes abnormal lipid metabolism and produces a high concentration of lipid peroxide ${ }^{1-3)}$, which in turn can cause biofunctional abnormalities ${ }^{4-6)}$.

A high concentration of lipid peroxide also increases inflammation-mediating substances, abnormal cytokine production, and the activation of the inflammatory signaling mechanism, and these can exert negative effects on the immune system ${ }^{7-9)}$. With the aim of developing nutraceuticals for lowering lipids and with antioxidant and anti-inflammatory effects, this study investigated the effects of SRE on lipids, anti-oxidation, and the concentration of pro-inflammatory cytokines in rats fed highly oxidized fat.

The concentrations of plasma free fatty acid and triglyceride (Table 2) were lower in the SRE groups than the control group, although the difference was not significant between control and $100 \mathrm{mg} / \mathrm{kg}$ SRE. The con-

Table 3. Effects of SRE on Plasma Total Cholesterol, HDL-Cholesterol and LDL-Cholesterol Concentration in Rat Fed Oxidized Fat

\begin{tabular}{lccc}
\hline \multicolumn{1}{c}{ Treatment } & $\begin{array}{c}\text { Total cholesterol } \\
(\mathrm{mg} / \mathrm{dl})\end{array}$ & $\begin{array}{c}\mathrm{HDL} \text {-cholesterol } \\
\text { (mg/dl) }\end{array}$ & $\begin{array}{c}\text { LDL-cholesterol } \\
(\mathrm{mg} / \mathrm{dl})\end{array}$ \\
\hline Control & $217.52 \pm 17.65^{\mathrm{c}}$ & $25.18 \pm 5.79^{\mathrm{b}}$ & $58.71 \pm 5.23^{\mathrm{b}}$ \\
SRE $(100 \mathrm{mg} / \mathrm{kg})$ & $188.49 \pm 21.52^{\mathrm{bc}}$ & $34.25 \pm 3.47^{\mathrm{a}}$ & $54.19 \pm 5.54^{\mathrm{ab}}$ \\
SRE $(200 \mathrm{mg} / \mathrm{kg})$ & $167.33 \pm 18.22^{\mathrm{ab}}$ & $35.11 \pm 3.95^{\mathrm{a}}$ & $52.38 \pm 5.47^{\mathrm{a}}$ \\
SRE (300 mg/kg) & $145.34 \pm 19.53^{\mathrm{a}}$ & $35.86 \pm 3.11^{\mathrm{a}}$ & $43.52 \pm 5.11^{\mathrm{a}}$ \\
\hline
\end{tabular}

Values are presented as mean \pm standard deviation.

SRE: Scutellariae Radix extract, HDL: high density lipoprotein, LDL: low density lipoprotein.

a,b,c Means in the same column with different superscripts are significantly different $(P<0.05)$. 
centrations of total plasma cholesterol and low density lipoprotein-cholesterol (Table 3) also decreased as the concentration of SRE increased, although the difference was not significant between control and SRE (100 $\mathrm{mg} / \mathrm{kg}$ )-treated groups. The concentrations of blood free fatty acid, total cholesterol, and triglyceride are closely related to the degree of intracorporeal lipid accumulation, showing that SRE can decrease the lipid level to prevent adult diseases, and optimally inhibit intracorporeal lipid accumulation. The HDL-cholesterol concentration was significantly higher in all of the SRE groups than in the control group. These results showed that SRE has positive effects on intracorporeal lipid metabolism and is effective in preventing adult diseases. The liver total cholesterol and triglyceride concentrations (Table 4) were lower in the SRE groups than in the control group, although the difference was not significant between control and $100 \mathrm{mg} / \mathrm{kg}$ SRE. Since lipid is

Table 4. Effects of SRE on Liver Total Cholesterol and Triglyceride Concentration in Rat Fed Oxidized Fat

\begin{tabular}{lcc}
\hline Treatment & $\begin{array}{c}\text { Total cholesterol } \\
(\mathrm{mg} / \mathrm{g})\end{array}$ & $\begin{array}{c}\text { Triglyceride } \\
(\mathrm{mg} / \mathrm{dl})\end{array}$ \\
\hline Control & $19.11 \pm 1.85^{\mathrm{c}}$ & $28.34 \pm 2.12^{\mathrm{b}}$ \\
SRE $(100 \mathrm{mg} / \mathrm{kg})$ & $17.34 \pm 1.53^{\mathrm{bc}}$ & $25.19 \pm 1.95^{\mathrm{ab}}$ \\
SRE $(200 \mathrm{mg} / \mathrm{kg})$ & $14.55 \pm 1.62^{\mathrm{ab}}$ & $22.48 \pm 2.51^{\mathrm{a}}$ \\
SRE $(300 \mathrm{mg} / \mathrm{kg})$ & $13.98 \pm 1.74^{\mathrm{a}}$ & $21.52 \pm 1.91^{\mathrm{a}}$ \\
\hline
\end{tabular}

Values are presented as mean \pm standard deviation.

SRE: Scutellariae Radix extract.

a,b,c Means in the same column with different superscripts are significantly different $(P<0.05)$.

Table 5. Effects of SRE on Plasma and Liver TBARS in Rat Fed Oxidized Fat

\begin{tabular}{lcc}
\hline \multicolumn{1}{c}{ Treatment } & $\begin{array}{c}\text { Plasma TBARS } \\
(\mathrm{nmmoles} \text { MDA } / \mathrm{ml})\end{array}$ & $\begin{array}{c}\text { Liver TBARS } \\
(\mathrm{nmoles} \text { MDA/g) }\end{array}$ \\
\hline Control & $29.75 \pm 4.14^{\mathrm{b}}$ & $34.11 \pm 5.93^{\mathrm{b}}$ \\
SRE $(100 \mathrm{mg} / \mathrm{kg})$ & $25.22 \pm 4.39^{\mathrm{ab}}$ & $25.44 \pm 4.57^{\mathrm{a}}$ \\
SRE $(200 \mathrm{mg} / \mathrm{kg})$ & $21.14 \pm 3.75^{\mathrm{a}}$ & $24.38 \pm 4.21^{\mathrm{a}}$ \\
SRE $(300 \mathrm{mg} / \mathrm{kg})$ & $20.18 \pm 3.49^{\mathrm{a}}$ & $21.71 \pm 3.58^{\mathrm{a}}$ \\
\hline
\end{tabular}

Values are presented as mean \pm standard deviation.

SRE: Scutellariae Radix extract, TBARS: thiobarbituric acid, MDA: malone dialdehyde.

${ }^{a, b}$ Means in the same column with different superscripts are significantly different $(P<0.05)$. synthesized as well as analyzed in the liver, the hepatic lipid concentration is usually kept within quantum satis. But in some cases it may differ according to the diet or enzyme-activity-related factors. In this study, since all of the rats had the same intake of the same diet, the results suggest that SRE can influence hepatic lipid synthesis or lipolysis.

Table 5 indicates that the plasma and hepatic TBARS concentrations decreased in the SRE groups, although the difference of the plasma TBARS was not significant between control and $100 \mathrm{mg} / \mathrm{kg}$ SRE. This demonstrates that SRE contains functional substances that decrease the concentration of intracorporeal peroxide, and are similar to previous findings of natural plant resources containing antioxidant ingredients ${ }^{10,11}$.

Table 6 indicates that the activities of GOT and GPT decreased in the SRE groups. The present results show that SRE exerts effects to improve liver function.

Table 6. Effects of SRE on levels of GOT and GPT in the Plasma of Rat Fed Oxidized Fat

\begin{tabular}{lcc}
\hline \multicolumn{1}{c}{ Treatment } & GOT (karmen unit) & GPT (karmen unit) \\
\hline Control & $45.17 \pm 3.59^{\mathrm{b}}$ & $48.29 \pm 3.37^{\mathrm{b}}$ \\
SRE (100 mg/kg) & $37.55 \pm 3.27^{\mathrm{a}}$ & $42.11 \pm 3.24^{\mathrm{ab}}$ \\
SRE (200 mg/kg) & $37.31 \pm 3.62^{\mathrm{a}}$ & $41.57 \pm 3.65^{\mathrm{a}}$ \\
SRE (300 mg/kg) & $32.38 \pm 4.12^{\mathrm{a}}$ & $37.83 \pm 3.15^{\mathrm{a}}$ \\
\hline
\end{tabular}

Values are presented as mean \pm standard deviation.

SRE: Scutellariae Radix extract, GOT: glutamic oxaloacetic transaminase, GPT: and glutamic pyruvic transaminase.

${ }^{a, b}$ Means in the same column with different superscripts are significantly different $(P<0.05)$.

Table 7. Effects of SRE on Glutathione Peroxidase, Superoxide Dismutase and Catalase Activity in Lives of Rat Fed Oxidized Fat

\begin{tabular}{lccc}
\hline \multicolumn{1}{c}{ Treatment } & \multicolumn{2}{c}{ GSH-px } & SOD (unit/mg \\
& (nM/n/mg/protein) & protein) & $\begin{array}{c}\text { CAT }(\mu M \\
\mathrm{H}_{2} \mathrm{O}_{2} / \mathrm{min} / \mathrm{mg} \\
\text { protein) }\end{array}$ \\
\hline Control & $121.83 \pm 21.22^{\mathrm{a}}$ & $3.58 \pm 1.44^{\mathrm{a}}$ & $61.54 \pm 10.72^{\mathrm{a}}$ \\
SRE (100 mg/kg) & $173.11 \pm 24.38^{\mathrm{b}}$ & $5.32 \pm 1.59^{\mathrm{ab}}$ & $87.14 \pm 11.38^{\mathrm{b}}$ \\
SRE (200 mg/kg) & $189.45 \pm 25.61^{\mathrm{b}}$ & $6.11 \pm 1.27^{\mathrm{b}}$ & $95.17 \pm 15.38^{\mathrm{b}}$ \\
SRE (300 mg/kg) & $207.61 \pm 25.27^{\mathrm{b}}$ & $6.24 \pm 1.75^{\mathrm{b}}$ & $98.65 \pm 13.21^{\mathrm{b}}$ \\
\hline
\end{tabular}

Values are presented as mean \pm standard deviation.

SRE: Scutellariae Radix extract, GSH-px: glutathione peroxidase, SOD: liver superoxide dismutase, CAT: liver catalase.

${ }_{a, b}$ Means in the same column with different superscripts are significantly different $(P<0.05)$. 
Sung-Man Kim and Yun-Yeop Cha: Effects of Scutellariae Radix Extract on Lipid Metabolism, Oxidation

Table 8. Effects of SRE on Cytokines Levels in the Plasma of Rat Fed Oxidized Fat

\begin{tabular}{lllll}
\hline \multicolumn{1}{c}{ Treatment } & $\mathrm{IL}-1 \beta(\mathrm{pg} / \mathrm{ml})$ & $\mathrm{IL}-6(\mathrm{pg} / \mathrm{ml})$ & TNF- $\alpha(\mathrm{pg} / \mathrm{ml})$ & $\mathrm{IL}-10(\mathrm{pg} / \mathrm{ml})$ \\
\hline Control & $21.88 \pm 1.14^{\mathrm{b}}$ & $31.92 \pm 3.15^{\mathrm{b}}$ & $32.11 \pm 2.73^{\mathrm{b}}$ & $18.17 \pm 2.05^{\mathrm{a}}$ \\
SRE (100 mg/kg) & $20.75 \pm 1.59^{\mathrm{b}}$ & $29.58 \pm 3.17^{\mathrm{ab}}$ & $29.43 \pm 3.27^{\mathrm{b}}$ & $21.55 \pm 1.98^{\mathrm{a}}$ \\
SRE (200 mg/kg) & $19.57 \pm 1.38^{\mathrm{ab}}$ & $28.23 \pm 3.21^{\mathrm{a}}$ & $27.95 \pm 3.11^{\mathrm{ab}}$ & $22.37 \pm 2.13^{\mathrm{a}}$ \\
SRE (300 mg/kg) & $17.18 \pm 1.23^{\mathrm{a}}$ & $23.76 \pm 2.43^{\mathrm{a}}$ & $21.58 \pm 2.92^{\mathrm{a}}$ & $27.48 \pm 1.95^{\mathrm{b}}$ \\
\hline
\end{tabular}

Values are presented as mean \pm standard deviation.

SRE: Scutellariae Radix extract, IL: interleukin, TNF: tumor necrosis factor.

${ }^{a, b}$ Means in the same row with different superscripts are significantly different $(P<0.05)$.

Table 9. Effects of SRE on Cytokines in Rat Fed Oxidized Fat

\begin{tabular}{lllll}
\hline \multicolumn{1}{c}{ Treatment } & $\mathrm{IL}-1 \beta(\mathrm{pg} / \mathrm{mg})$ & $\mathrm{IL}-6(\mathrm{pg} / \mathrm{mg})$ & TNF- $\alpha(\mathrm{pg} / \mathrm{mg})$ & $\mathrm{IL}-10(\mathrm{pg} / \mathrm{mg})$ \\
\hline Control & $26.91 \pm 2.14^{\mathrm{b}}$ & $17.24 \pm 1.91^{\mathrm{b}}$ & $2.49 \pm 0.93^{\mathrm{NS}}$ & $1.54 \pm 0.55^{\mathrm{NS}}$ \\
SRE $(100 \mathrm{mg} / \mathrm{kg})$ & $21.39 \pm 2.21^{\mathrm{a}}$ & $13.88 \pm 1.67^{\mathrm{ab}}$ & $1.96 \pm 0.84^{\mathrm{NS}}$ & $1.71 \pm 0.63^{\mathrm{NS}}$ \\
SRE $(200 \mathrm{mg} / \mathrm{kg})$ & $21.15 \pm 1.85^{\mathrm{a}}$ & $12.95 \pm 1.58^{\mathrm{a}}$ & $1.85 \pm 0.91^{\mathrm{NS}}$ & $1.78 \pm 0.72^{\mathrm{NS}}$ \\
SRE (300 mg/kg) & $19.38 \pm 1.79^{\mathrm{a}}$ & $11.39 \pm 1.25^{\mathrm{a}}$ & $1.51 \pm 0.73^{\mathrm{NS}}$ & $1.95 \pm 0.71^{\mathrm{NS}}$ \\
\hline
\end{tabular}

Values are presented as mean \pm standard deviation.

SRE: Scutellariae Radix extract, IL: interleukin, TNF: tumor necrosis factor, NS: not significantly different $(P>0.05)$.

${ }^{a, b}$ Means in the same row with different superscripts are significantly different $(P<0.05)$.

Table 7 indicates that the activities of GSH-Px, SOD, and CAT were significantly increased in the SRE groups compared to the control group. Intracorporeal peroxide accumulation is closely interrelated with the activities of antioxidant enzymes. In this study, the activities of GSH-Px, SOD, and CAT corresponded to the changes in TBARS concentrations. These results suggest that functional substances in SRE act on the activities of antioxidant enzymes and the biologic responses in the production inhibition and lysis promotion of intracorporeal peroxide. Table 8 lists the plasma concentrations of IL-1 $1 \beta$, IL-6, TNF- $\alpha$, and IL-10. The concentrations of the pro-inflammatory cytokines IL-1 $1 \beta$, IL -6 , and $\mathrm{TNF}-\alpha$ were decreased in the SRE groups, while that of the anti-inflammatory cytokine IL-10 was increased. Although the concentrations of $\mathrm{TNF}-\alpha$ and IL-10 did not differ significantly among the treatment groups, the liver cytokines (Table 9) were consistent with those found in plasma cytokines, with IL-1 $\beta$, IL-6, and TNF- $\alpha$ being decreased in the SRE groups and IL-10 being increased.

Decreased pro-inflammatory cytokines indicates an inhibitory effect inflammatory response, thus functional substances in SRE contributed to improving the inflammatory response. These results indicate that SRE could be used in the production of nutraceuticals for lowering lipids and exerting anti-oxidation and anti-inflammatory effects.

\section{References}

1. Takayama S, Kahn CR, Kubo K, Foley JE. Alterations in insulin receptor autophosphorylation in insulin resistance: correlation with altered sensitivity to glucose transport and antilipolysis to insulin. J Clin Endocrinol Metab. 1988 ; 66(5) : 992-9.

2. Arner P, Pollare T, Lithell H, Livingston JN. Defective insulin receptor kinase in human skeletal muscle in obesity and type 2 (non-insulin-dependent) diabetes mellitus. Diabetologia. 1987; 30(6) : 437.

3. Kolterman OG, Insel J, Saekow M, Olefsky JM. Mechanism of insulin resistance in human obesity. J Clin Invest. 1980 ; 65(6) : 1272-84.

4. Saito W. Interaction between lipid peroxide formation and nutritional status. J JPN Soc Nutr Food Sci. 1988 ; 41(5) : 343-9.

5. Vergroeson AT. Physiological effects of dietary linoleic acid. Nutr Rev. 1997 ; 35(1) : 1-9.

6. Bidlack WR, Tappel AL. Damage to microsomal membrane by 
lipid peroxidation. Lipids. $1973 ; 8(4): 177-8$.

7. Hotamisligil GS, Shargill NS, Spiegelman BM. Adipose expression of tumor necrosis factor- $\alpha$ : direct role in obesity-linked insulin resistance. Science. 1993 ; 259(5091) : 87-91.

8. Ronald MK, Mary W. Obesity: impact on cardiovascular disease. Circulation. 1998 ; 98(8) : 1472-6.

9. Robert HE, Ronald MK. American heart association call to action: obesity as a major risk factor for coronary heart disease. Circulation. 1998 ; 97(21) : 2099-100.

10. Lee E, Choi MY, Oh HS. Effects of Powdered Siho (Bupleuri Radix) on serum and liver lipid composition and antioxidative capacity in rat fed high oxidized fat. Korean J Nutr. 2000 ; 33(5) : 502-6.

11. Lee E. Effects of powdered pine needle (Pinus densiflora seib et Zucc.) on serum and liver lipid composition and antioxidative. J Korean Soc Food Sci Nutr. 2003 ; 32(6) : 926-30.

12. Kang YH, Ha TY, Moon KD. Effects of pine needle extracts on serum and liver lipid contents in rats fed high fat diet. J Korean Soc Food Nutr. 1996 ; 25(3) : 367-73.

13. Ishikawa T, Suzukawa M. Effect of tea flavonoid supplementation on the susceptibility of low-density lipoprotein to oxidative modification. Am J Clin Nutr. 1997 ; 66(2) : 261-6.

14. Kim HC. Textbook of herbal pharmacology. Seoul : Jipmundang. 2001: 129-33

15. Middleton E Jr, Drzewiecki V. Naturally occuring flavonoids and human basophil histamine release. Int Archs Allergy Appl Immun. $1985 ; 77(1-2):$ 155-7.

16. Wagner H. Antihepatotoxic flavonoids. In: Cody V, editors. Plant flavonoids in biology and medicine, biochemical, pharmacological and structure: activity relationships. New York : Alan R. Liss. 1986 : 545-58.

17. Middleton E Jr, Harborne JB, Beretz A. Plant flavonoids in biology and medicine II. biochemical, cellular and medicineal properties. New York : Alan R. Liss. 1988 : 61-5.
18. Middleton E Jr, Harborne JB. Plant flavonoids in biology and medicine, biochemical, pharmacological, structure-activity relationship. New York : Alan R. Liss. 1986 : 429-40.

19. Kubo MY, Kimura T, Odani T, Tani T, Namba K. Studies on Scutellariae radix. II. The antibacterial substance. Planta Med. $1981 ;$ 43(2) : 194-201.

20. Kubo MH, Matusuda Y, Kimura H, Okuda M, Higashino T, Tani T, et al. Stidies on Scutellariae Radix. VII. Anti-arthrictic and anti-inflammatory action of methanolic extract and flavonoid components from Scutellariae Radix. Chem Pharm Bull. 1984 ; 32(7) : 2724-9.

21. Tie H, Jin GB, Cho GB, Fumi S, Cyong JC. Evaluation of the anti-inflammatory effect of baicalein on dextran sulfate sodium-induced colitis in mice. Planta Med. 2002 ; 68(3) : 266-8.

22. Kaneda TK, Ueda N. Kasanka shishitsu shiken ho. Tokyo : Hirokawasyoten. 1987 : 58-9.

23. Buege JA, Aust SD. Microsomal lipid peroxidation. In: Fleischer S, editors. Packer leds methods in enzymelogy. London : Academic Press. 1978 : 302-9.

24. Ohkawa H, Ohishi N, Yagi K. Assay for lipid peroxide in animal tissues by thiobarbituric acid reaction. Anal Biochem. 1979; 95(2) : 351-8.

25. Levander OA, DeLoach DP, Morris VC, Moser PB. Platelet glutathione peroxidase activity as an index of selenium status in rats. J Nutr. 1983 ; 113(1) : 55-63.

26. Flohe L, Becker R, Brigelius R, Lengfelder E, Otting F. Convenient assays for superoxide dismutase. CRC Handbook of free radicals and antioxidants in Biomedicine. Boca Raton, FL : CRC Press, Inc. 1992 : 287-93.

27. Johnson LH, Hakan Borg LA. A spectro phtometric method for determination of catalase activity in small tissue samples. Anal Biochem. 1988 ; 174(1) : 331-6. 


\title{
황금추출물이 과산화지질을 급여한 흰쥐의 지질대사, 산화반응 및 전염증성 Cytokine의 생산에 미치는 영향
}

\author{
김성만, 차윤엽 ${ }^{1}$ \\ 가톨릭관동대학교 의과대학 의료경영학과, ${ }^{1}$ 상지대학교 한의과대학 한방재활의학과
}

목적: 본 연구는 황금추출물이 과산화지질을 장기간 급여한 흰쥐의 지질대사, 산화반응 및 전염증성 cytokine의 생산에 미치는 영 향을 검토하기 위해 수행되었다.

방법: 10 주 동안 흰쥐에게 과산화지질을 과량으로 급여하여 생체 내에 과잉의 지질을 축적시킨 후, 황금추출물을 6 주간 급여하였 다. 그 후, 각 처리군별로 지질대사, 산화반응 및 전염성 cytokine의 생산에 미치는 영향을 조사했다.

결과: 혈액 내 유리지방산, 총지질, 총콜레스테롤, low density lipoprotein-cholesterol과 간장 내 총지질, 총콜레스테롤이 황금추출 물 처리군에서 하락했다. 혈액 및 간장의 thiobarbituric acid 농도가 황금추출물 처리군에서 하락했다. 간장 내 항산화효소들 (glutathione peroxidase, liver catalase, liver superoxide dismutase)의 활성치가 황금처리군에서 상승하였다. 전염증성 cytokine (interleukin [IL]-1 $\beta$, tumor necrosis factor- $\alpha$, IL-6)의 농도는 황금추출물 처리군에서 하락했다. 반면에 IL-10의 농도는 황금추출물 처리군에서 증가했다.

결론: 이상의 결과들을 종합해 보면, 황금 추출물은 과산화지질을 급여한 비만쥐의 지질대사, 항산화반응 및 항염증반응에 긍정적 인 효과를 나타내었음을 인식시켜 준다. 